\title{
Sound columns in electoral campaigns in Albania
}

\author{
Ilir Ramdani
}

\begin{abstract}
Albania culture soundtrack entered too late. Sound columns newness brought in Albania in 2003. Edi Rama Rama will be remembered as the candidate who brought a unique innovation in the campaigns developed in Albania. Rama 2003 when running for reelection for mayor of Tirana, the Albanian song he chose as a soundtrack to the campaign, in which he revealed himself as the protagonist. Rama sang "Our Tirona", together with three boys of "WEST Side Family". Output of Edi Rama as a singer, with lyrics written by himself, starting with the string "Too much noise, too much noise" was completed and was launched with a video, the filming of which were realized in the most popular areas of Tirana, of center to the outskirts. This song not only became a hit in Albania in 2003, but also affected the Rama achieved victory in front of his former rival, the right-wing candidate, Spartak Ngjela.
\end{abstract}

Keywords: Socialist Party, Democratic Party, mobilization,

\section{Introduction}

It has become increasingly trendy for politicians to recruit musicians to promote and mobilize for support through music and musicians.

This is owing to the fact that many contestants for elective positions have found music to be an ideal tool for political mobilization and for spreading across their campaign messages to the electorate or voters on radio, television and other forms of mass media'.

Recently, various musicians have identified themselves with political parties such as the ruling PS and opposition PD contesting the August elections and have their songs used by these political parties for political campaigns.

To many, this has stirred an exciting debate on whether musicians should take sides in the political process such as elections through their music. Others have argued to the contrary, that musicians, like any other members of society, have the right to participate freely in the social and political process of a country.

Some musicians feel that their music as a social tool can be used by any member of society including politicians and political parties as long as they mutually consent to such use for political campaigns.

Although the conclusion to this debate cannot be entirely arrived at, it is clear that music in Albania has continued to play a major role in the social and political identity formation in the everyday life of people throughout society. ${ }^{2}$

In Albania, music has for many generations played a big role in expressing, unifying and bringing peaceful co-existence among communities.

Music has always been the most visible attempt employed by Albanians to listen to themselves.

$1 \mathrm{http}: / / a l . e j o-o n l i n e . e u / m e d i a t-e-r e j a / f u s h a t a-e l e k t o r a l e-n e n-n d i k i m i n-e-t e k n o l o g j i v e-d h e-m e d i a v e-t e-r e j a$

2 http://www.doktoratura.unitir.edu.al/wp-content/uploads/2015/11/Doktoratura-Eva-Londo-Fakulteti-i-Histori-Filologjise-Departamenti-iGazetarise.pdf 
Albanian music is a powerful medium of communication, through which human actions and reactions are expressed. It provides a forum to mirror the society so that members can understand things better and learn more about life.

In many instances, Albanian music focuses on the teaching of morality, building restraints into the psyche or minds of people and as a mechanism of conflict resolution in society.

In Albania, for instance, the fight against occupation was catalyzed by music and other forms of popular culture.

These popular dances and music thus were historically deployed not only as social entertainment for Albanians but to champion the social, economic and political welfare of Albanian under occupation rule.

Sound columns history of election campaigns in Albania

From "Our Tirona" Rama 2003 new song to the Democratic Party in this campaign

West during election campaigns soundtrack is probably the most important detail, and the song is dedicated to finding exceptional importance. Albania culture soundtrack entered too late. Sound columns newness brought in Albania in 2003.

Edi Rama will be remembered as the candidate who brought a unique innovation in the campaigns developed in Albania. Rama 2003 when running for reelection for mayor of Tirana, the Albanian song he chose as a soundtrack to the campaign, in which he revealed himself as the protagonist. Rama sang "Our Tirona", together with three boys of "West Side Story". Output of Edi Rama as a singer, with lyrics written by himself, starting with the string "Too much noise, too much noise" was completed and was launched with a video, the filming of which were realized in the most popular areas of Tirana, of center to the outskirts. This song not only became a hit in Albania in 2003, but also affected the Rama achieved victory in front of his former rival, the right-wing candidate, Spartak Ngjela.

But would come in 2009 that the tradition of songs campaigns returned with the song still sung and lampooned "Albania is changing" Democratic Party sung by Elita 5, Wiley, Leonora Poloska, Elvana, Soni Malaj, Çiljeta, Stine and Bojken Lako. Socialist Party came out with the song "Rise" sung by EEST Side Family and Edi Rama, as in 2003.

Another political group that came up with a song G99 campaign was led by Erion Veliaj. The group released the song "Do we" sung by Alban Skenderaj. Those are the column voice of all election campaigns in Albania. ${ }^{1}$ Also in 2013 during the campaign of Albanian Youth Forum Euro socialist the song Born Free by Kid Rock was the sound column whom accompanied the whole campaign.

\section{ELECTIONS 2011}

Sound -Kolona Basha: The song "I Gotta Feeling" and "The Black

Sound -Kolona Edi Rama: The song "Breath and Life" and "Audiomachine"

\section{ELECTIONS 2009}

Sound -Kolona PS: The song "Rise" sung by West Side Family together with Edi Rama.

Sound -Kolona DP Song "Albania is changing" sung by Elita 5, Wiley, Leonora Poloska, Elvana, Soni Malaj, Çiljeta, Stine and Bojken Lako.

\section{ELECTIONS 2007}

Sound OKolona Edi Rama: "Echo" is sung from "West Side Story" together with Edi Rama.

1http://www.tiranaobserver.al/kolonat-zanore-me-te-famshme-te-fushatave-zgjedhore-ne-shqiperi/ 
Sound -Kolona Sokol Olldashi: "Give me back my city", sung by Ermal Mamaqi, in association with Olsen.

Elections 2005

Sound -Kolona PS: The song "Thunderstruck" sung by AC / DC

Soundtrack PD: The song "The final countdown" sung by "Europe"

\section{ELECTIONS 2003}

Sound -Kolona Edi Rama: The song "Our Tirona" singing "West Side Story" and Edi Rama.

Rama and "Our Tirona"

Edi Rama will be remembered as the candidate who brought a unique innovation in the campaigns developed in Albania. Rama 2003 when running for reelection for mayor of Tirana, the Albanian song he chose as a soundtrack to the campaign, in which he revealed himself as the protagonist. Song of the Democratic Party for elections June 23, 2013

The lyrics was written by Armand Trebicka while singing the "Elita 5", Elvana, Soni Malaj, UNIC, Vesa Luma, Vedat Ademi, Renis Rybak, Eni Koci. The song talks about Albania changing and closed with strings "Our motive is you, ours Albania, so every day changes."

We are the change

Verse 1:

At any moment, this place changes,

I see on the horizon the future, to the horizon.

Today belongs to us, the future we expect,

and pride awakens us, we are the change.

refrain:

We change, we change,

all hands to unite.

We change, we change,

on every challenge we will win.

Verse 2:

Under blue skies and no clouds

It awaits us all a new day

a new hope.

Our motivation is you, ours Albania

therefore every day change.

Bibliography

http://al.ejo-online.eu/mediat-e-reja/fushata-elektorale-nen-ndikimin-e-teknologiive-dhe-mediave-te-reja 
http://www.doktoratura.unitir.edu.al/wp-content/uploads/2015/11/Doktoratura-Eva-Londo-Fakulteti-i-Histori-FilologjiseDepartamenti-i-Gazetarise.pdf

http://www.tiranaobserver.al/kolonat-zanore-me-te-famshme-te-fushatave-zgjedhore-ne-shqiperi/

http://www.gazetadita.al/fushata-gara-per-imazh/

http://www.gazetatema.net/web/2013/01/15/born-free-kenga-e-fushates-se-ps-se-video/

http://www.arkivalajmeve.com/ohu-kenga-e-West-Side-Family-qe-do-te-shogeroje-Ramen-gjate-fushates.250326/ 